Article

\title{
Sintering Behavior and Technological Properties of Low-Temperature Porcelain Tiles Prepared Using a Lithium Ore and Silica Crucible Waste
}

\author{
Lihua Peng ${ }^{1,2}$ and Shan Qin ${ }^{2, *}$ \\ 1 School of Science, Inner Mongolia University of Science and Technology, Baotou 014000, China; \\ ppku@pku.edu.cn \\ 2 School of Earth and Space Sciences, Peking University, Beijing 100871, China \\ * Correspondence: sqin@pku.edu.cn; Tel.: +86-010-6275-1166
}

Received: 1 October 2019; Accepted: 22 November 2019; Published: 26 November 2019

\begin{abstract}
Porcelain tiles are a building material that has been widely used in recent years and that consumes substantial resources during the sintering process. This study reports on the production of low-temperature porcelain tiles by using low-grade lithium ore (LO) and silica crucible waste (SCW) in a new $\mathrm{SiO}_{2}-\mathrm{Al}_{2} \mathrm{O}_{3}-\mathrm{Na}_{2} \mathrm{O}-\mathrm{K}_{2} \mathrm{O}-\mathrm{Li}_{2} \mathrm{O}$ system. The firing temperature of the porcelain tiles was reduced from $1260{ }^{\circ} \mathrm{C}$ to $1070{ }^{\circ} \mathrm{C}$ by adding $30 \%$ LO instead of feldspar in a modified triaxial ceramic body, and SCW was recycled and used as a raw material. These actions help to reduce the carbon emissions produced during sintering and achieve sustainable development. The effect of phase transitions on the sintering and technological properties of the porcelain tiles was studied by quantitative phase analysis, using X-ray diffraction (XRD). Secondary mullite (0-19\%) can be formed at $1040-1100{ }^{\circ} \mathrm{C}$, where more quartz and cristobalite will be retained, which increases the rupture modulus of the porcelain tiles. While the vitreous phase increases rapidly at $1100-1160{ }^{\circ} \mathrm{C}$, the closed pores $(0.1-33.1 \%)$ will simultaneously expand, causing a decrease in compactness. The results show that low-grade $\mathrm{LO}$ (with a cost similar to that of feldspar) allows for the production of porcelain tiles with better process performance at lower temperatures $\left(\leq 1100^{\circ} \mathrm{C}\right)$.
\end{abstract}

Keywords: porcelain tiles; lithium ore; silica crucible waste; firing temperature; water absorption; rupture modulus

\section{Introduction}

Porcelain tiles have been widely used as building materials in recent years because of their excellent technical properties, such as water absorption $(\leq 0.5 \%)$, rupture modulus $(30-75 \mathrm{MPa})$, deep-abrasion resistance (120-160 $\left.\mathrm{mm}^{3}\right)$, chemical resistance, and high fracture toughness [1-4]. For example, the total consumption of ceramic tiles in the United States in 2018 was $289,000,000 \mathrm{~m}^{2}$ [5]. Conventionally, porcelain tiles are triaxial ceramics made from quartz (10-25\%), clay (40-45\%), and feldspathic materials (30-50\%) by wet-grinding the raw materials, then dry-pressing, fast-drying, and fast-single-firing the tiles at $1150-1300{ }^{\circ} \mathrm{C}[6-9]$. With the consideration of protecting the environment and reducing the costs, considerable research has been devoted to reducing the firing temperature and replacing natural minerals with industrial-waste products.

The use of lithium-bearing minerals as a liquid-phase sintering aid has been investigated in various ceramics, to reduce the firing temperature or to improve the thermal-shock resistance of the ceramics [10-15]. The effects of $\mathrm{CaO}-\mathrm{Li}_{2} \mathrm{O}-\mathrm{K}_{2} \mathrm{O}-\mathrm{Na}_{2} \mathrm{O}$ as fluxing agents in porcelain ceramic tiles was discussed by Zhou et al. [16], who showed that a multicomponent eutectic system can produce a liquid phase at a lower temperature. However, the influence of a lithium-bearing fluxing agent 
on the sintering and technological properties of porcelain tiles has not been systematically studied. Moreover, the price of high-grade spodumene $\left(5-7 \% \mathrm{Li}_{2} \mathrm{O}\right)$ is approximately $5-10$ times higher than that of feldspar [17], which restricts the industrial application of lithium-bearing minerals in porcelain tiles. In this study, a low-grade lithium ore (LO) with $2.7 \% \mathrm{Li}_{2} \mathrm{O}$ is introduced as a raw material to replace feldspar. Since this low-grade LO has a price similar to that of feldspar, this LO can be applied in practical industry.

To achieve the recycling of resources, several studies have focused on finding alternative materials to replace the conventional minerals in ceramic bodies [18], such as (i) mineral waste, including spodumene tailings [19], granite waste [20], marble waste [21], gneiss rock waste [22], and petroleum oily sludge [23]; and (ii) industrial waste, including waste glass [1,3], fly ash [24,25], polished tile waste [26], and furnace slag [27,28]. Additionally, new minerals have recently been discovered that have also been considered for the manufacture of ceramic tiles, such as new feldspar [6] and new clay [29,30]. Silica crucibles are the containers used for preparing polycrystalline silicon, and they can only be used once because of the phase change occurring during the ingot production process [31]. The annual amount of silica crucible waste (SCW) produced in China is estimated to be 100,000 tons [32], which wastes resources and introduces environmental hazards.

The main purpose of this study was to evaluate the effect of a low-grade $\mathrm{LO}\left(2.7 \% \mathrm{Li}_{2} \mathrm{O}\right)$ on reducing the firing temperature of porcelain tiles and to achieve the recycling of SCW. Porcelain tiles were obtained at firing temperatures of $1070-1160{ }^{\circ} \mathrm{C}$ and $1180-1280^{\circ} \mathrm{C}$, and a certain amount $(20 \%)$ of quartz and varying amounts ( $0-50 \%$ ) of feldspar were replaced by SCW and LO, respectively. The experimental results are systematically discussed in terms of "chemical composition and firing temperature $\rightarrow$ phase composition and microstructure $\rightarrow$ technological properties" based on $\mathrm{SiO}_{2}-\mathrm{Al}_{2} \mathrm{O}_{3}-\mathrm{Na}_{2} \mathrm{O}-\mathrm{K}_{2} \mathrm{O}-\mathrm{Li} 2 \mathrm{O}$ system. The final result of this study was the successful production of low-temperature porcelain tiles by introducing LO and crucible waste, which are helpful for reducing energy consumption in the preparation process of ceramics.

\section{Materials and Methods}

\subsection{Base Materials}

Four types of raw materials were used to manufacture the porcelain tiles in the laboratory, namely, LO, calcined kaolin, feldspar, and SCW, all of which are readily available as industrial products. LO and calcined kaolin were purchased from Borun (Zhengzhou, China). Feldspar was purchased from Fuhua (Guangzhou, China). SCW was provided by the crucible manufacturer (Yangzhong, China). Fluorite $\left(99.99 \% \mathrm{CaF}_{2}\right)$ for XRD quantification was purchased from Aladdin (Shanghai, China). The raw materials were characterized according to inductively coupled plasma optical emission spectrometer (ICP-OES, Blue Sop mode, Spectro, Germany) in Table 1. About $50 \mathrm{mg}$ of carbonate-free sample was dissolved in a Teflon beaker by a mixture of $3 \mathrm{~mL}$ of concentrated $\mathrm{HF}$ and $1 \mathrm{~mL}$ of concentrated $\mathrm{HNO}_{3}$ at $120^{\circ} \mathrm{C}$ for $12 \mathrm{~h}$. The solution was dried down in a hotplate, and the residue was then dissolved in $4 \mathrm{~mL}$ of concentrated $\mathrm{HNO}_{3}$ at $120^{\circ} \mathrm{C}$ for $12 \mathrm{~h}$. After it was dried down in a hotplate, the residue was then dissolved in $2 \% \mathrm{HNO}_{3}$, for elemental composition analyses. The major and minor elemental compositions were determined by an ICP-OES with error below 5\%. The elemental compositions were calculated on the carbonate-free basis, and all major and minor elements are considered as oxides (i.e., $\mathrm{Na}_{2} \mathrm{O}, \mathrm{MgO}, \mathrm{Al}_{2} \mathrm{O}_{3}, \mathrm{SiO}_{2}, \mathrm{~K}_{2} \mathrm{O}, \mathrm{CaO}, \mathrm{FeO}, \mathrm{MnO}, \mathrm{P}_{2} \mathrm{O}_{5}, \mathrm{TiO}_{2}$, and $\mathrm{Li}_{2} \mathrm{O}$ ). The silica content was determined by the bulk sample weight (carbonate-free) minus the total weight of all other oxides. LO was mainly used to replace for feldspar, and the SCW was used to replace quartz, to produce modified triaxial ceramics. The $\mathrm{LO}$ can provide $\mathrm{Li}_{2} \mathrm{O}$, in addition to $\mathrm{Na}_{2} \mathrm{O}$ and $\mathrm{K}_{2} \mathrm{O}$, as a fluxing agent. The SCW is composed mainly of $\mathrm{SiO}_{2}$ with small amounts of impurities, thus forming the basis for the substitution of quartz with SCW. 
Table 1. Chemical composition of raw materials.

\begin{tabular}{ccccc}
\hline wt. $\%$ & SCW & Calcined Kaolin & Feldspar & LO \\
\hline $\mathrm{SiO}_{2}$ & 99.7 & 64.6 & 77.6 & 68.2 \\
$\mathrm{Al}_{2} \mathrm{O}_{3}$ & 0.2 & 33.3 & 12.4 & 19.9 \\
$\mathrm{Fe}_{2} \mathrm{O}_{3}$ & 0.1 & 0.4 & 0.6 & 0.2 \\
$\mathrm{CaO}$ & $<0.1$ & 0.8 & 0.9 & 0.1 \\
$\mathrm{MgO}$ & $<0.1$ & 0.1 & 0.2 & $<0.1$ \\
$\mathrm{~K}_{2} \mathrm{O}$ & $<0.1$ & 0.1 & 5.4 & 6.1 \\
$\mathrm{Na}_{2} \mathrm{O}$ & $<0.1$ & $<0.1$ & 2.7 & 2.2 \\
$\mathrm{MnO}$ & $<0.1$ & $<0.1$ & $<0.1$ & 0.4 \\
$\mathrm{TiO}_{2}$ & $<0.1$ & $<0.1$ & $<0.1$ & $<0.1$ \\
$\mathrm{P}_{2} \mathrm{O}_{5}$ & $<0.1$ & $<0.1$ & $<0.1$ & 0.2 \\
$\mathrm{Li}_{2} \mathrm{O}$ & $<0.1$ & $<0.1$ & $<0.1$ & 2.7 \\
\hline
\end{tabular}

\subsection{Preparation of Porcelain Tiles}

Table 2 shows the formulation of the experimental samples for the porcelain tiles. This study performed two series of experiments. In the first series, the $\mathrm{LO}$ was added to the mixtures as a replacement for feldspar, and these samples were designated S10, S20, S30, S40, and S50, which represent the percentage of feldspar that was replaced, i.e., 10, 20,30, 40, and $50 \mathrm{wt} . \%$, respectively. The content of crucible waste $(20 \%)$ and calcined kaolin $(30 \%)$ used in the ceramic bodies was fixed. S10-S50 ceramics were all fired at temperatures of $1040^{\circ} \mathrm{C}, 1070{ }^{\circ} \mathrm{C}, 1100^{\circ} \mathrm{C}, 1130{ }^{\circ} \mathrm{C}$, and $1160^{\circ} \mathrm{C}$.

Table 2. Formulation of experimental bodies for porcelain tiles.

\begin{tabular}{ccccc}
\hline wt. $\%$ & SCW & Calcined Kaolin & Feldspar & LO \\
\hline S10 & 20 & 30 & 40 & 10 \\
S20 & 20 & 30 & 30 & 20 \\
S30 & 20 & 30 & 20 & 30 \\
S40 & 20 & 30 & 10 & 40 \\
S50 & 20 & 30 & 0 & 50 \\
R1180-R1280 & 20 & 30 & 50 & 0 \\
\hline
\end{tabular}

The second series of experiments are reference experiments that were based on the first series, in which all the ceramics are prepared by using a fixed proportion of raw material, including $20 \%$ SCW, $30 \%$ calcined kaolin, and 50\% feldspar. These sintered samples were designated R1180, R1200, R1220, $\mathrm{R} 1240, \mathrm{R} 1260$, and R1280, which indicate the sintering temperatures of $1180^{\circ} \mathrm{C}, 1200{ }^{\circ} \mathrm{C}, 1220^{\circ} \mathrm{C}$, $1240{ }^{\circ} \mathrm{C}, 1260^{\circ} \mathrm{C}$, and $1280^{\circ} \mathrm{C}$, respectively.

The raw materials were first mixed in the designed ratio specified in Table 2, using wet-grinding with an alumina medium in a nylon jar for $8 \mathrm{~h}$. The speed of the roller-ball mill (WZM-1, Haoqiang, Yixing, China) was set to $90 \mathrm{r} / \mathrm{min}$. The slips were then dried in an oven at $110{ }^{\circ} \mathrm{C}$ for $12 \mathrm{~h}$, and the dried cakes were crushed and passed through an 80-mesh sieve. Humidification using 7-8\% water with a $0.7 \%$ carboxymethylcellulose sodium content was carried out, and the test samples with diameters of $51 \mathrm{~mm}$ and heights of $7 \mathrm{~mm}$ were prepared by uniaxial pressing at $30 \mathrm{MPa}$. The finished products were dried in an electric oven at $110{ }^{\circ} \mathrm{C}$ for $10 \mathrm{~h}$. Finally, the samples were fired in a box furnace (KSL-1700A2, HF-Kejing, Heifei, China), at maximum temperatures of $1040-1160{ }^{\circ} \mathrm{C}$ and $1180-1280^{\circ} \mathrm{C}$, with a holding time of $20 \mathrm{~min}$. The heating rate and cooling rate were both $5^{\circ} \mathrm{C} / \mathrm{min}$, and the temperature was naturally cooled after cooling to $500^{\circ} \mathrm{C}$.

\subsection{Sample Characterization}

The crystalline phases of the raw materials were determined by X-ray diffraction $(\mathrm{XRD}, \mathrm{D} / \mathrm{max}-\mathrm{rB}$, Rigaku, Tokyo, Japan) analysis, with $\mathrm{Cu}$ X-ray radiation at $40 \mathrm{kV}$ and $100 \mathrm{~mA}$. Powder XRD was conducted over a reflection angle range of $2 \theta=15^{\circ}-55^{\circ}$, with a counting step of $0.01^{\circ}$ and a scanning 
speed of $4^{\circ}(2 \theta) \mathrm{min}^{-1}$. The phase composition of the porcelain tiles was quantitatively determined by using the Reference Intensity Ratio and X-ray powder diffraction (RIR-XRPD), using $20 \% \mathrm{CaF}_{2}$ as an internal standard [33]. The experimental error was within 5\%. The mineralogy of the raw materials was assessed via XRD under the same conditions. Furthermore, the polished surface of the fired samples was observed and analyzed by using a scanning electron microscope (SEM, Quanta 200FEG, FEI, Hillsboro, OR, USA), with secondary electrons at $10 \mathrm{kV}$.

Firing shrinkage was evaluated from the variation in the diameter of the circular samples $(\mathrm{QB} / \mathrm{T}$ 1548-2015) [34]. The porcelain tiles were evaluated for their water absorption (Ev), as expressed in Equation (1); bulk density (B), as expressed in Equation (2); and for open porosity, as expressed in Equation (3), according to GB/T 3810.3-2006 [35], using a boiling method. The properties were obtained according to the following equations:

$$
\begin{gathered}
E_{V}=\frac{M_{2}-M_{1}}{M_{1}} \\
B=\frac{M_{1}}{M_{2}-M_{3}} \\
P_{a}=\frac{M_{2}-M_{1}}{M_{2}-M_{3}}
\end{gathered}
$$

where $M_{1}$ is the dry mass, $M_{2}$ is the water saturated mass, and $M_{3}$ is the submerged (hydrostatic scale weight) mass.

The rupture modulus of the fired samples was measured by conducting three-point bending tests with an electronic universal testing machine (CMT-4305, Sans, Shenzhen, China), at a loading rate of $0.1 \mathrm{~mm} / \mathrm{min}$ (GB/T 3810.4-2006) [36]. The rupture modulus (R) was calculated by using Equation (4):

$$
R=\frac{3 P_{t} L}{2 b h^{2}}
$$

where $L, b$, and $h$ are the span, width, and depth of the specimens, respectively, and $P_{t}$ is the ultimate load.

The true density was measured, according to QB/T 1010-2015 [37], using the pycnometer method.

The total porosity $\left(P_{t}\right)$ was calculated by using Equation (5):

$$
P_{t}=\frac{D_{t}-D_{b}}{D_{t}} \times 100 \%
$$

where $P_{t}, D_{t}$, and $D_{b}$ are the total porosity, true density, and bulk density of the samples, respectively.

The closed porosity $\left(P_{c}\right)$ was calculated by using Equation (6):

$$
P_{c}=P_{t}-P_{a}
$$

where $P_{c}, P_{t}$, and $P_{a}$ represent the closed porosity, total porosity, and open porosity of the samples, respectively.

\section{Results and Discussion}

\subsection{Phase Composition of the Raw Materials}

As shown in Figure 1, the crystalline phases of the raw materials were determined by XRD analysis. The phases of LO include spodumene, muscovite, Na-feldspar, K-feldspar, and quartz. Feldspar is a mixed mineral composed of Na-feldspar, K-feldspar, and quartz (Figure 1b). The calcined kaolin used to be exposed to a high temperature of $1200^{\circ} \mathrm{C}$, and, in this process, various forms of $\mathrm{H}_{2} \mathrm{O}$ were removed. Different from the high loss on ignition (7-14\%) of industrial clay [1-3,19], calcined kaolin will not produce gas in the sintering process, which is conducive to improving the compactness of ceramic. The phases of the calcined kaolin consist of quartz, mullite, cristobalite, and a vitreous phase 
(Figure 1c). The SCW is mainly composed of fused silica and cristobalite (Figure 1d). The crystalline content of cristobalite can be measured according to an external standard method [31], using Equation (7):

$$
W_{c}=4.3 \times 10^{-4} I_{\mathcal{C}}-3.53
$$

where $W_{C}$ is the crystalline content of $\alpha$-cristobalite, and $I_{C}$ is the intensity of the (101) diffraction peak in the XRD pattern. Refinement shows that the SCW is composed of $57 \%$ cristobalite and $44 \%$ silica. Knowing the mineral composition of the raw materials, along with their chemical composition (Table 1), is helpful for clear analysis of the phase changes of the raw materials that occur in the sintering process.
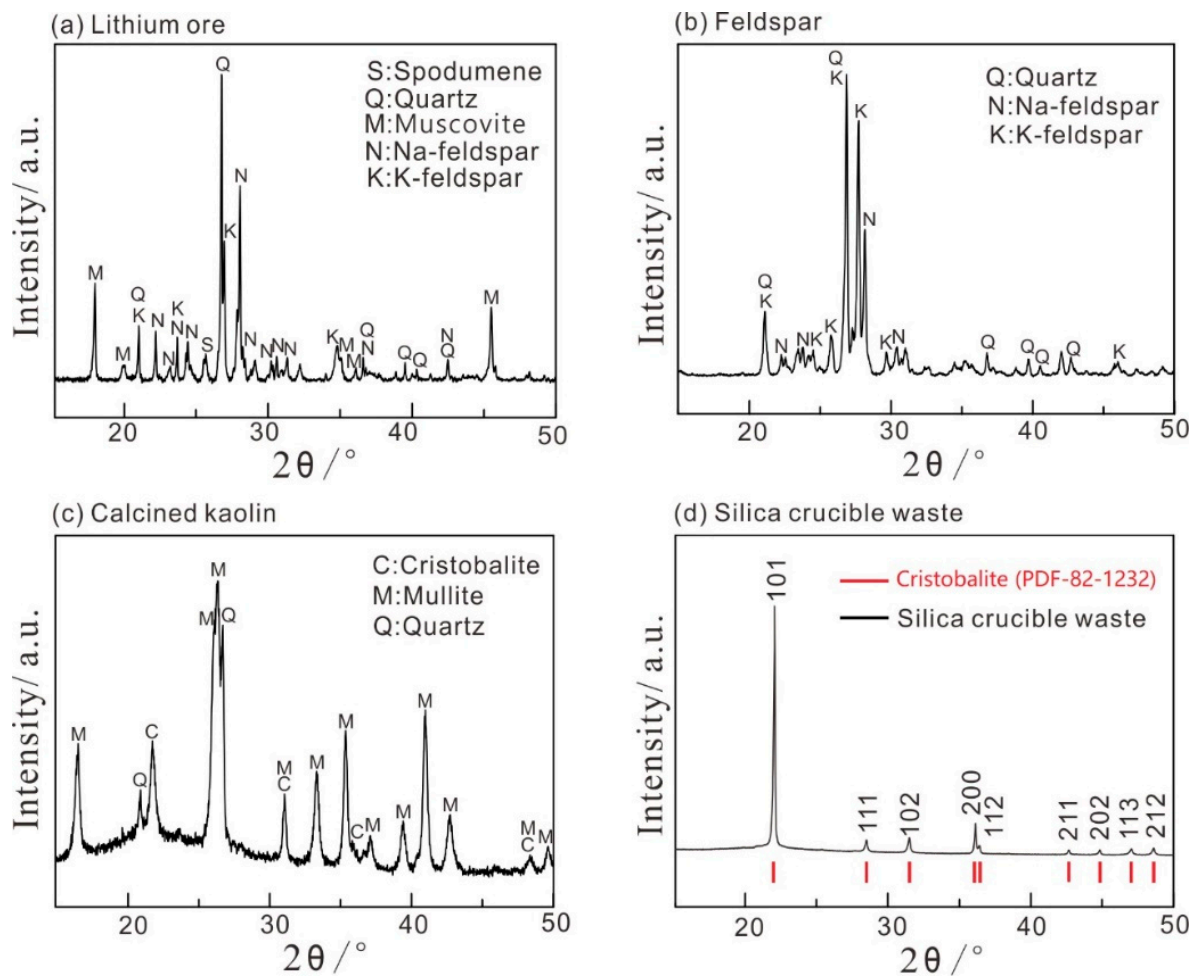

Figure 1. XRD patterns and mineral phases of raw materials: (a) SCW; (b) feldspar; (c) calcined kaolin; and (d) LO.

\subsection{Phase Transitions in the Sintering Process}

Figure 2 shows the phase change trends of the fired samples with different LO contents and firing temperatures, including cristobalite, quartz, spodumene, mullite, feldspar, and vitreous phases. Quantitative calculation of different phases is based on XRD patterns (Supplementary Materials, Table $\mathrm{S} 1$ and files $\mathrm{XRD} 1$ ). Figure 3 shows the normalized ternary diagrams of the fired samples, which correspond to the $\mathrm{SiO}_{2}-\mathrm{Al}_{2} \mathrm{O}_{3}-\mathrm{Na}_{2} \mathrm{O}-\mathrm{K}_{2} \mathrm{O}-\mathrm{Li}_{2} \mathrm{O}$ system. The vitreous phase content first increases and then decreases with the increase in $\mathrm{LO}$ (Figure 2a), and the vitreous phase content reaches a maximum value with a $\mathrm{LO}$ content of $30 \%$. On the one hand, the introduction of $\mathrm{Li}_{2} \mathrm{O}$ to the base of $\mathrm{Na}_{2} \mathrm{O}$ and $\mathrm{K}_{2} \mathrm{O}$ can further reduce the formation temperature of the liquid phase during combustion [16]. On the other hand, the increase rate of $\mathrm{Al}_{2} \mathrm{O}_{3}$ is much higher than that of other components with the increase in LO content, which makes the sintered samples produce more mullite and spodumene (Figure 3a-c), thus reducing the proportion of the vitreous phase. 


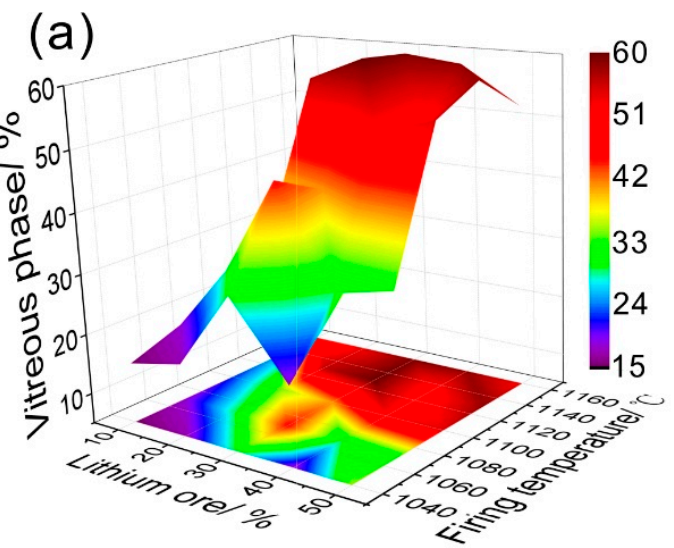

(c)
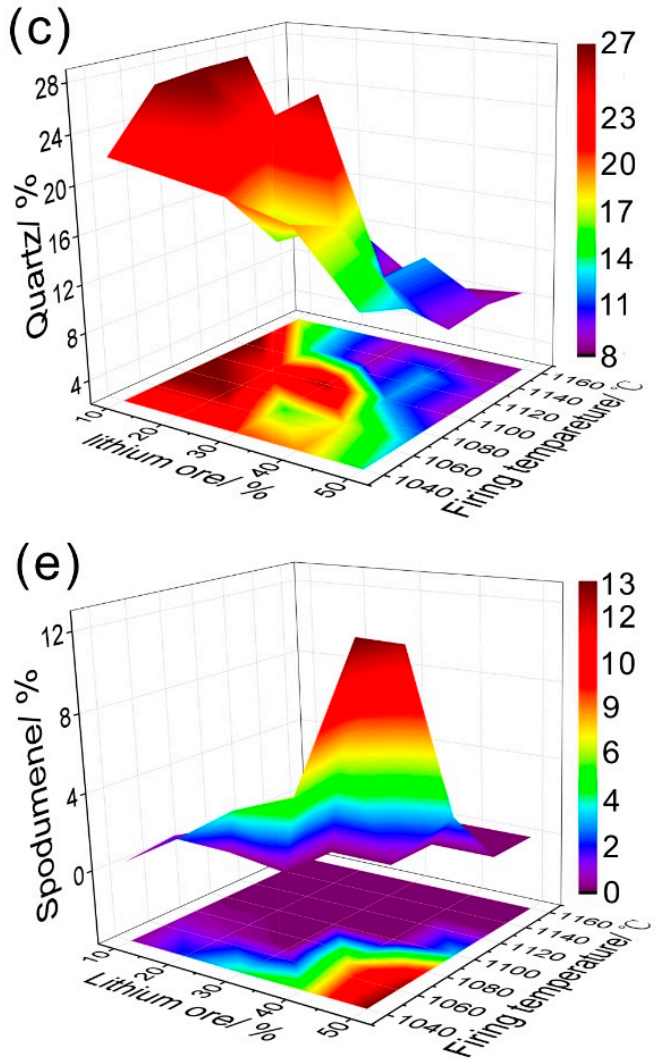
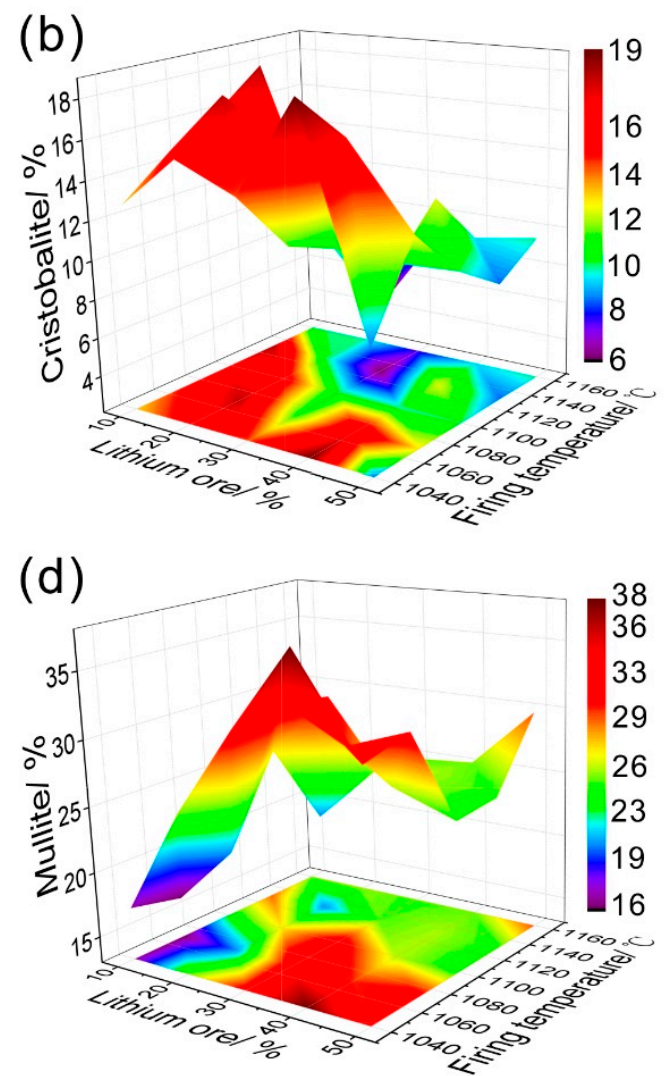

(f)

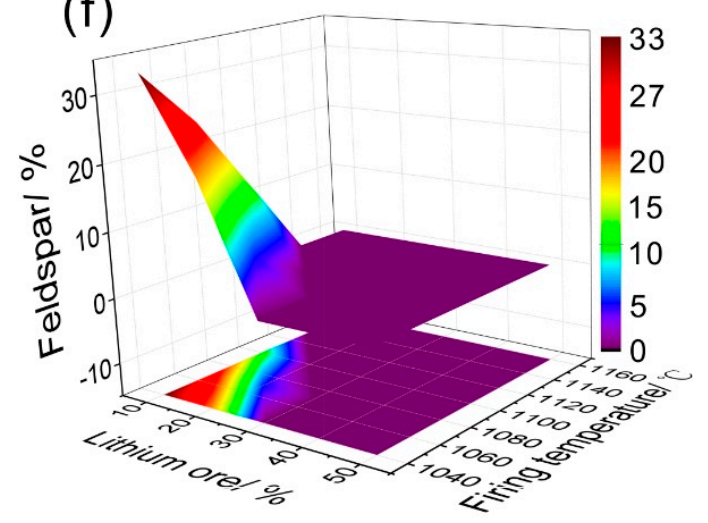

Figure 2. Quantitative phase analyses for the (a) vitreous phase, (b) cristobalite, (c) quartz, (d) mullite, (e) spodumene, and (f) feldspar of porcelain tiles with different LO contents $(10 \%, 20 \%, 30 \%, 40 \%$, and $50 \%$ ) and firing temperatures $\left(1040{ }^{\circ} \mathrm{C}, 1070{ }^{\circ} \mathrm{C}, 1100{ }^{\circ} \mathrm{C}, 1130{ }^{\circ} \mathrm{C}\right.$, and $\left.1160{ }^{\circ} \mathrm{C}\right)$.

The amount of cristobalite and quartz slowly decreases with increasing temperature and LO content (Figure 2b,c) because they are more involved in sintering reactions to form the vitreous phase and mullite (Figure 3a,b). The correlation between cristobalite and the vitreous phase is higher than that of quartz, which seems to imply that cristobalite only participates in the co-melting reaction, while quartz participates in the co-melting reaction and the mullite formation reaction at the same time. Quartz undergoes a series of phase transitions of $\alpha$-quartz, $\beta$-quartz, and metastable cristobalite under the temperatures of this experiment $[38,39]$, so it is more likely to participate in high-temperature reactions than the stable cristobalite. 


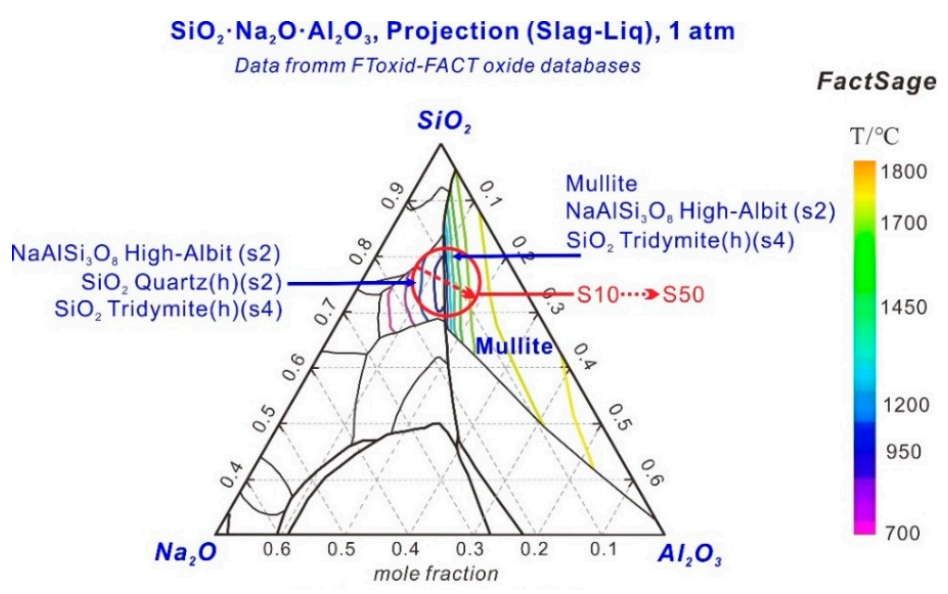

(a)

$\mathrm{SiO}_{2} \cdot \mathrm{K}_{2} \mathrm{O} \cdot \mathrm{Al}_{2} \mathrm{O}_{3}$, Projection (Slag-Liq), $1 \mathrm{~atm}$ Data fromm FToxid-FACT oxide databases

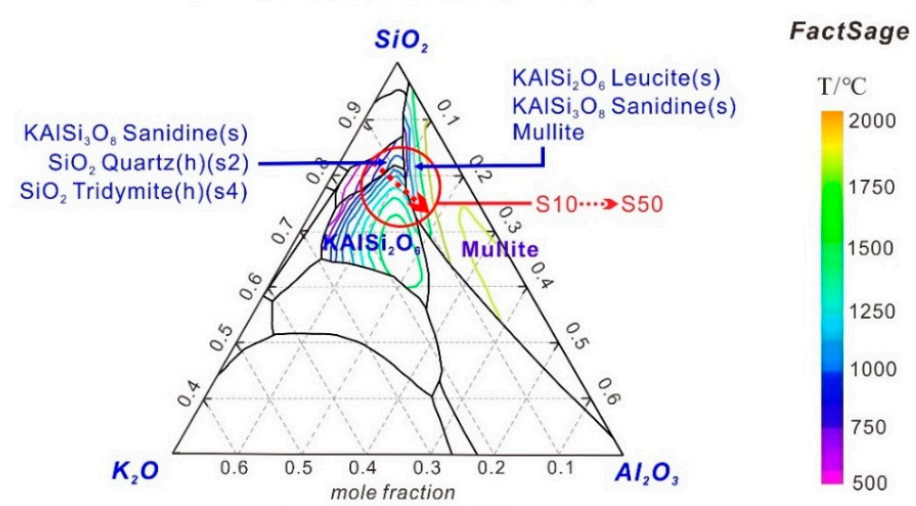

(b)

$\mathrm{SiO}_{2} \cdot \mathrm{Li}_{2} \mathrm{O} \cdot \mathrm{Al}_{2} \mathrm{O}_{3}$, Projection (Slag-Liq), $1 \mathrm{~atm}$ Data from ACerS-NIST phase equilibria diagrams database

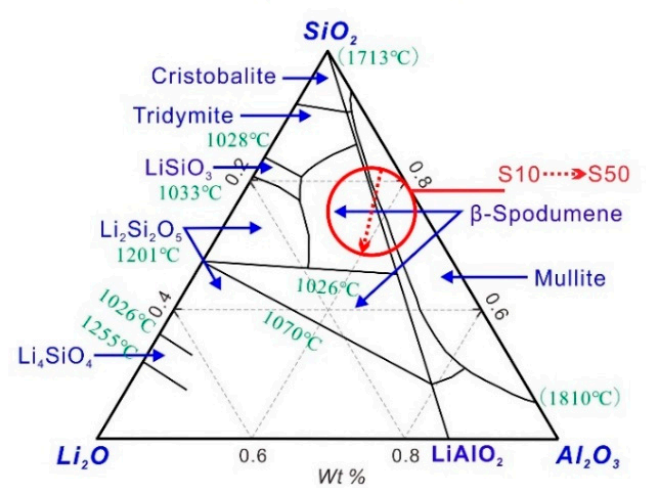

(c)

Figure 3. Composition trends and phases of samples $\mathrm{S} 10-\mathrm{S} 50$ in system of (a) $\mathrm{SiO}_{2}-\mathrm{Na}_{2} \mathrm{O}-\mathrm{Al}_{2} \mathrm{O}_{3}$, (b) $\mathrm{SiO}_{2}-\mathrm{K}_{2} \mathrm{O}-\mathrm{Al}_{2} \mathrm{O}_{3}$, and (c) $\mathrm{SiO}_{2}-\mathrm{Li}_{2} \mathrm{O}-\mathrm{Al}_{2} \mathrm{O}_{3}$.

The trend of the mullite content as a function of the LO content and firing temperature is shown in Figure 2d. The mullite content is generally higher than $19 \%$ in the range of $1070-1100{ }^{\circ} \mathrm{C}$, with a maximum value of $38 \%$, while the mullite content in the mixed raw materials is $19 \%$, which is calculated by using XRD quantitative analysis (Figure 1) and the raw material ratios (Table 2). The result indicates that there is a crystallization of mullite (0-19\%) during the firing process, especially under $1040-1100{ }^{\circ} \mathrm{C}$. In previous studies, $20 \%$ of mullite was formed in ceramic bodies at $1200{ }^{\circ} \mathrm{C}$, with the flux of $\mathrm{Na}_{2} \mathrm{O}$ and $\mathrm{K}_{2} \mathrm{O}$, which shows the addition of $\mathrm{Li}_{2} \mathrm{O}$ reduced the temperature of sintering 
reaction. The phase present should be secondary mullite $\left(3 \mathrm{Al}_{2} \mathrm{O}_{3} \cdot 2 \mathrm{SiO}_{2}\right)$, since there is no clay present in the raw materials [40-42]. This secondary mullite is likely to be acicular crystals and will improve the mechanical properties of the ceramics [19,43]. On the other hand, the mullite content is mostly lower than $26 \%$ when the firing temperature exceeds $1100{ }^{\circ} \mathrm{C}$. This finding is because the stability of mullite decreases at increasing temperatures for the $\mathrm{SiO}_{2}-\mathrm{Al}_{2} \mathrm{O}_{3}-\mathrm{Na}_{2} \mathrm{O}$ and $\mathrm{SiO}_{2}-\mathrm{Al}_{2} \mathrm{O} 3-\mathrm{K}_{2} \mathrm{O}$ systems (Figure $3 \mathrm{a}, \mathrm{b}$ ), and a large amount of $\mathrm{Al}_{2} \mathrm{O}_{3}$ and $\mathrm{SiO}_{2}$ enters the vitreous phase at these temperatures, rather than only the secondary mullite.

As shown in Figure 2e,f, the residual spodumene gradually increases with increased LO, and no feldspar could be detected in the fired samples with LO contents exceeding $30 \%$. Moreover, the muscovite detected in the raw materials (Figure 1a) was not observed in the final samples, which means that all the muscovite melted at firing temperatures exceeded $1040^{\circ} \mathrm{C}$.

\subsection{Microstructure Analysis}

The effects of the firing temperature and LO content on the porosity of the samples are presented in Figure 4 (Supplementary Materials, Table S2). The open porosity of most of the samples decreases rapidly with increases in the $\mathrm{LO}$ content or firing temperature (Figure 4a). When the LO content is less than $20 \%$, the samples with an open porosity of less than $10 \%$ can be obtained only at relatively high firing temperatures $\left(\geq 1100^{\circ} \mathrm{C}\right)$. When the LO content is $30-50 \%$, samples with an open porosity less than $1 \%$ can be prepared at lower firing temperatures $\left(\geq 1070{ }^{\circ} \mathrm{C}\right)$, indicating that $\mathrm{LO}$ improves the sintering behavior [16]. The closed porosity of the samples S10-S50 increases rapidly with increases in the firing temperature, especially above $1100{ }^{\circ} \mathrm{C}$ (Figure $4 \mathrm{~b}$ ), which is due to the closing of the open pores and the expansion of the volume of the closed pores at higher sintering temperatures. The minimum value of total porosity in this study is $2.9 \%$, which is among the lowest values reported for ceramic tiles made from waste minerals $[1,4,21,44]$.
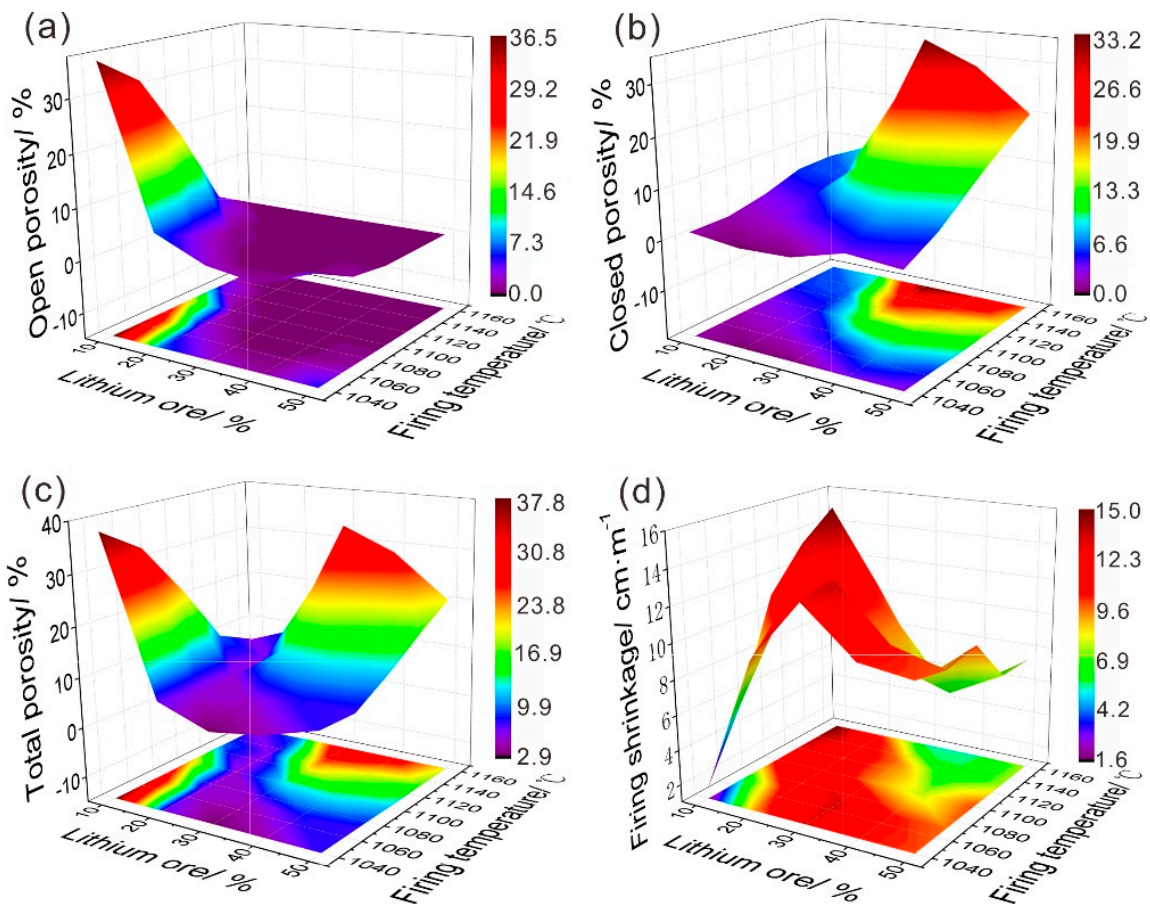

Figure 4. Trend of the (a) open porosity, (b) closed porosity, (c) total porosity, and (d) firing shrinkage as a function of $\mathrm{LO}$ content $(10 \%, 20 \%, 30 \%, 40 \%$, and $50 \%)$ and firing temperature $\left(1040{ }^{\circ} \mathrm{C}, 1070{ }^{\circ} \mathrm{C}\right.$, $1100{ }^{\circ} \mathrm{C}, 1130{ }^{\circ} \mathrm{C}$, and $\left.1160{ }^{\circ} \mathrm{C}\right)$.

The samples with higher total porosity are concentrated in two regions at the edge of Figure 4c: (i) LO contents and firing temperatures below $20 \%$ and $1100{ }^{\circ} \mathrm{C}$, respectively, and (ii) LO contents 
and firing temperatures exceeding $20 \%$ and $1100{ }^{\circ} \mathrm{C}$, respectively. Samples with lower total porosity $(<10 \%)$ are concentrated in the diagonal area of Figure $3 c$, in which the vitreous phase content is $34-61 \%$. When the vitreous phase content is below or above this range, the total porosity of the samples increases rapidly. Moreover, the firing shrinkage of all the samples ranges from $1.6 \mathrm{~cm} / \mathrm{m}$ to $15.0 \mathrm{~cm} / \mathrm{m}$. This firing shrinkage forms an area with high brightness (red) along the diagonal of Figure $4 \mathrm{~d}$, in which the firing shrinkage of these samples is higher than other areas, while the porosity of the samples in this area is also lower (Figure $4 \mathrm{c}$ ).

Figure 5a-j shows the individual effects of the sintering temperature and LO content on the microstructures of samples, respectively. As shown in Figure 5a-e, when the LO content is fixed at $40 \%$, the closed pores in the ceramic body gradually change from irregular gaps to regular circles with increases of the firing temperature. The small pores gradually disappear, and the larger pores gradually expand, as the sintering temperature exceeds $1100{ }^{\circ} \mathrm{C}$. On the other hand, as the LO content increases from $10 \%$ to $50 \%$ (Figure $5 \mathrm{f}-\mathrm{j}$ ), the total porosity first increases and then decreases at a firing temperature of $1130{ }^{\circ} \mathrm{C}$, and then reaches a maximum for a LO content of $40 \%$, which is similar to the distribution trend of the vitreous phase content (Figure 2a). Higher values of closed porosity from the ceramic compositions containing more glass vitreous phase were also observed by others $[3,45,46]$, and it was speculated that the total increase in porosity was caused by entrapment of air in the relatively viscous melt or gas release from raw materials [44]. This paper determines that this phenomenon can be explained by Ostwald ripening [47], the driving force of which is the decrease in the total interfacial free energy between the pores and the melt at high temperatures, and it can lead to the merging of pores and increasing the total volume of closed pores (Figure 3b). This phenomenon is particularly evident in ceramic tiles prepared by alluvial clay [31].

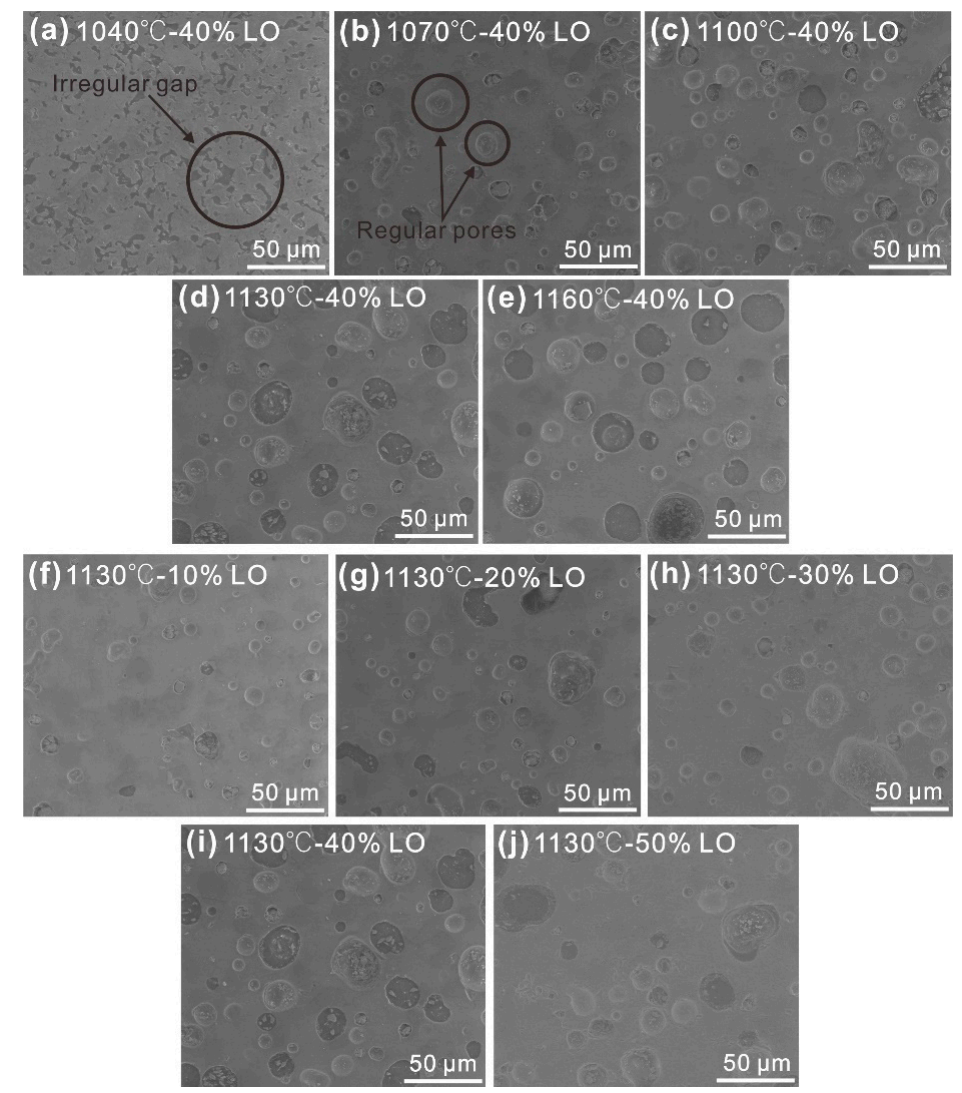

Figure 5. SEM micrographs of samples with an LO content of $40 \%$ fired at (a) $1040{ }^{\circ} \mathrm{C}$; (b) $1070{ }^{\circ} \mathrm{C}$; (c) $1100{ }^{\circ} \mathrm{C}$; (d) $1130{ }^{\circ} \mathrm{C}$; and (e) $1160{ }^{\circ} \mathrm{C}$. SEM micrographs of the samples fired at $1130{ }^{\circ} \mathrm{C}$ at the LO content of (f) $10 \%$, (g) $20 \%$, (h) $30 \%$, (i) $40 \%$, and (j) $50 \%$. 


\subsection{True Density and Bulk Density}

Figure 6 shows the distribution trends of the true density and the bulk density of the porcelain tiles (Supplementary Materials, Table S2). It was found that the true density of the ceramic bodies depends mainly on the phase composition of the samples, while the bulk density is mainly dependent on the porosity of the samples. The true density of samples ranges from $2.3 \mathrm{~g} / \mathrm{cm}^{3}$ to $2.6 \mathrm{~g} / \mathrm{cm}^{3}$, which is almost opposite to the distribution trend of the vitreous phase (Figure 2a). This finding results from the fact that the content of vitreous phase in most of the samples is between $20 \%$ and $60 \%$ and is far greater than that of other crystalline phases, which causes the vitreous phase to dominate the changes of the true density. On the other hand, the bulk density of the samples ranges from $1.5 \mathrm{~g} / \mathrm{cm}^{3}$ to $2.4 \mathrm{~g} / \mathrm{cm}^{3}$ (Figure $6 \mathrm{~b}$ ), with a distribution trend closely related to the total porosity (Figure 3c) and firing shrinkage (Figure 4d). The maximum values of the true density and bulk density of the ceramic bodies are similar to those of ceramic tiles prepared from waste glass [1-3,44], and the common feature between them is that they contain more flux, such as $\mathrm{Na}_{2} \mathrm{O}$, instead of $\mathrm{Al}_{2} \mathrm{O}_{3}$.

(a) True density

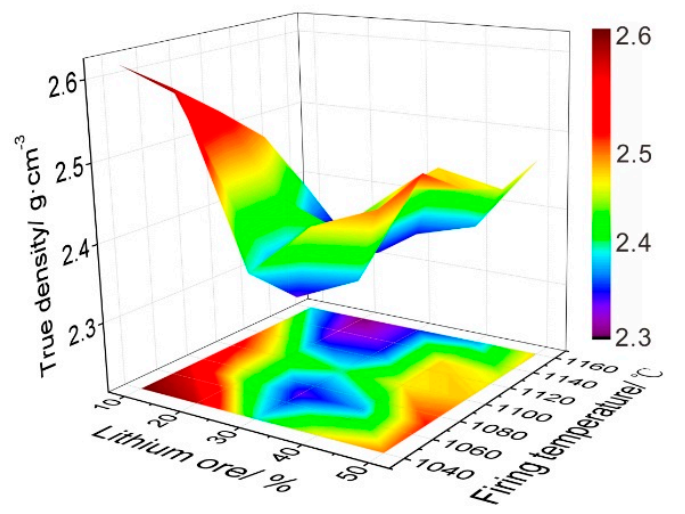

(b) Bulk density

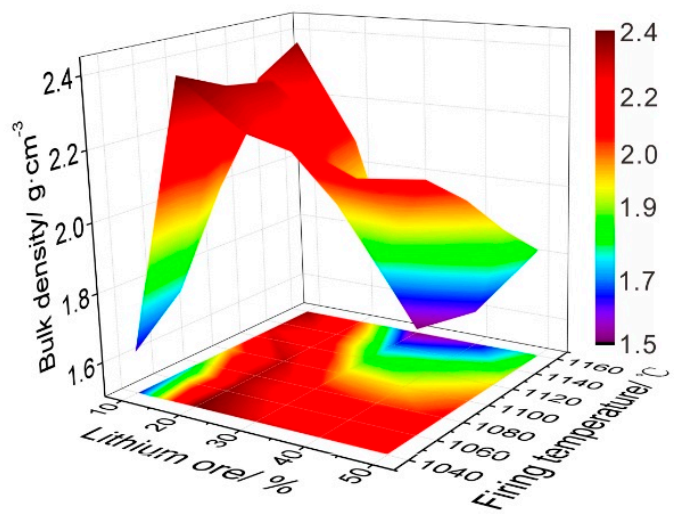

Figure 6. True density (a) and bulk density (b) of samples with different LO contents $(10 \%, 20 \%, 30 \%$, $40 \%$, and $50 \%$ ) and firing temperatures $\left(1040{ }^{\circ} \mathrm{C}, 1070{ }^{\circ} \mathrm{C}, 1100^{\circ} \mathrm{C}, 1130{ }^{\circ} \mathrm{C}\right.$, and $\left.1160{ }^{\circ} \mathrm{C}\right)$.

\subsection{Water Absorption and Rupture Modulus}

Figures 7 and 8 show the water absorption and rupture modulus for the samples (Supplementary Materials, Table S2), which are the most important technological parameters used in actual production and determine whether a type of porcelain tile can be used in the construction industry. According to the international standard ISO 13006 [48], porcelain tiles are ceramic tiles with water absorption $\leq 0.5 \%$ and a rupture modulus $\geq 35 \mathrm{MPa}$. When the $\mathrm{LO}$ content is $10 \%$ and $20 \%$, the lowest firing temperatures to achieve a water content below $0.5 \%$ are $1160{ }^{\circ} \mathrm{C}$ and $1100{ }^{\circ} \mathrm{C}$, respectively. The firing temperature can be reduced to $1070{ }^{\circ} \mathrm{C}$ for $\mathrm{LO}$ contents of $30-40 \%$, but the water absorption of the ceramic samples increases rapidly when the LO content exceeds $40 \%$. The water absorption depends on the degree of raw materials participating in the sintering reaction. When the $\mathrm{LO}$ content is increased, the sintering reaction is first enhanced by the increased amount of $\mathrm{Li}_{2} \mathrm{O}$ [16], and more glass phases are produced, which reduces the open porosity and water absorption of samples. However, as more LO is added, excessive $\mathrm{Al}_{2} \mathrm{O}_{3}$ leads to the increase of crystalline phases, resulting in the opposite trend. 


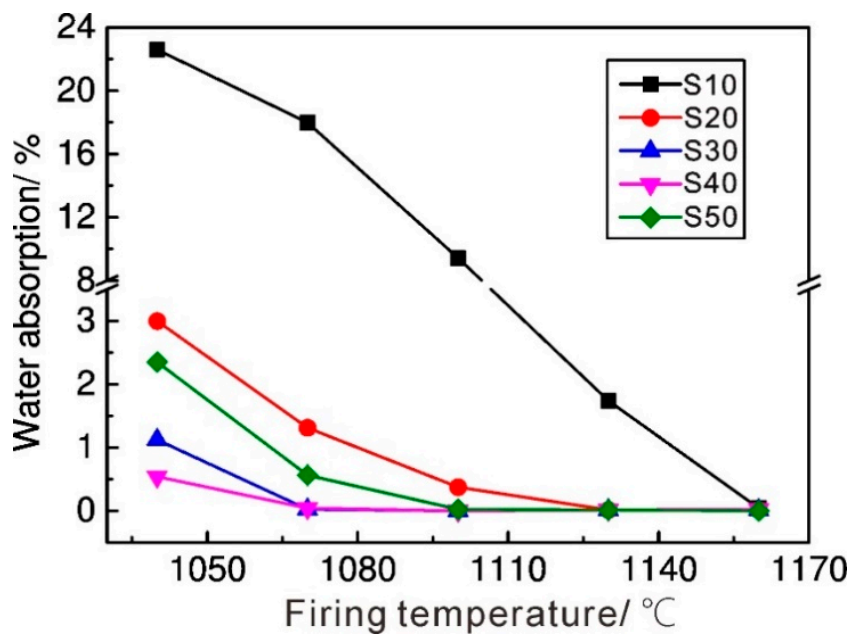

Figure 7. Water absorption of samples S10, S20, S30, S40, and S50 at different firing temperatures $\left(1040{ }^{\circ} \mathrm{C}, 1070{ }^{\circ} \mathrm{C}, 1100^{\circ} \mathrm{C}, 1130{ }^{\circ} \mathrm{C}\right.$, and $\left.1160^{\circ} \mathrm{C}\right)$.

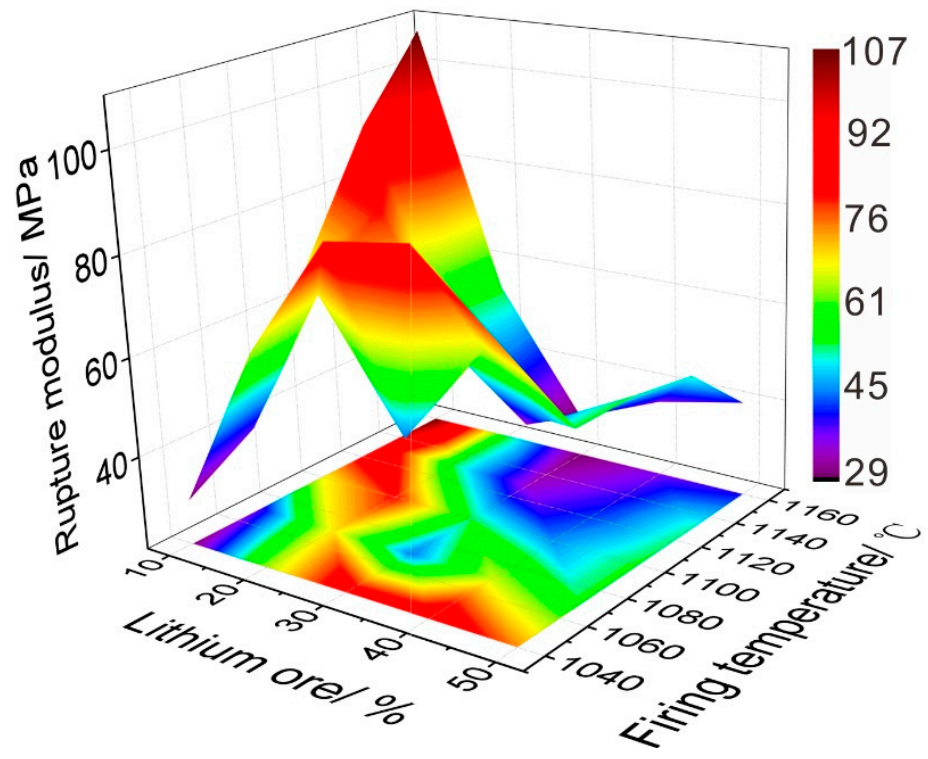

Figure 8. Rupture modulus of samples with different LO contents $(10 \%, 20 \%, 30 \%, 40 \%$, and $50 \%)$ and firing temperatures $\left(1040{ }^{\circ} \mathrm{C}, 1070{ }^{\circ} \mathrm{C}, 1100{ }^{\circ} \mathrm{C}, 1130{ }^{\circ} \mathrm{C}\right.$, and $\left.1160{ }^{\circ} \mathrm{C}\right)$.

As show in Figure 8, the rupture modulus reached a maximum of $107 \mathrm{MPa}$ for an LO content of $10 \%$ and firing temperature of $1160^{\circ} \mathrm{C}$, which is the highest reported value to date. The rupture modulus is highest in two ranges (red area): (i) LO contents exceeding $20 \%$ and firing temperatures below $1070{ }^{\circ} \mathrm{C}$ and (ii) LO contents below $20 \%$ and firing temperatures exceeding $1070{ }^{\circ} \mathrm{C}$. The quartz and cristobalite content (Figure $2 b, c)$ is higher in the first range, and the mullite content (Figure 2d) is higher in second range, implying that the crystalline phases enhance the rupture modulus of the samples. The secondary mullite formed during the sintering process might be acicular crystals and form a network structure in the matrix, improving the mechanical properties of the ceramics [43]. The samples with a high rupture modulus are concentrated in the diagonal region of Figure 8, where the vitreous phase content is in the medium value range (30-51\%), and the rupture modulus decreases rapidly when the vitreous phase content exceeds this range. In fact, the rupture modulus is almost completely inversely correlated with the vitreous-phase content, especially for firing temperatures exceeding $1100^{\circ} \mathrm{C}$, which is mainly due to the expansion of closed pores at higher temperatures (the 
blue region in Figure 8). The results show that lower firing temperatures are beneficial for obtaining porcelain tiles with improved mechanical properties.

\subsection{Environmental and Economic Effects}

To verify the effect of $\mathrm{LO}$ content on the firing temperature of porcelain tiles, a comparative experiment was carried out, in which the ceramic tiles were produced by SCW, calcined kaolin, and feldspar, without the addition of LO. As shown in Table 3 (Supplementary Materials, files XRD2), with the firing temperature increasing from $1180^{\circ} \mathrm{C}$ to $1280^{\circ} \mathrm{C}$, the Na-feldspar, K-feldspar, quartz, and cristobalite in the ceramic tiles gradually decrease and form more vitreous phase. Na-feldspar and K-feldspar completely disappeared when the firing temperature exceeded $1240{ }^{\circ} \mathrm{C}$, causing the vitreous phase content to stop increasing due to the lack of $\mathrm{Na}_{2} \mathrm{O}$ and $\mathrm{K}_{2} \mathrm{O}$ as flux. Generally, the diversification of flux in raw materials is beneficial to the sintering reaction. For example, with $\mathrm{Na}_{2} \mathrm{O}$, $\mathrm{K}_{2} \mathrm{O}$, and $\mathrm{CaO}$ as fluxes, Na-feldspar and $\mathrm{K}$-feldspar can react completely at $1180-1200{ }^{\circ} \mathrm{C}[1,3]$, and this temperature can be reduced to $1120^{\circ} \mathrm{C}$ with fluxes of $\mathrm{Na}_{2} \mathrm{O}, \mathrm{K}_{2} \mathrm{O}, \mathrm{CaO}$, and $\mathrm{Li}_{2} \mathrm{O}$ [16]. The mullite content in the raw material and fired samples are $2 \%$ and $9-13 \%$, respectively, which indicates that more than $6 \%$ of secondary mullite is formed during the sintering process.

Table 3. Phase composition of ceramic tiles produced by SCW, calcined kaolin, and feldspar (wt.\%).

\begin{tabular}{ccccccc}
\hline Ref & Vitreous Phase & Cristobalite & Quartz & K-Feldspar & Na-Feldspar & Mullite \\
\hline R1180 & 39 & 5 & 22 & 14 & 11 & 9 \\
R1200 & 51 & 5 & 21 & 8 & 5 & 10 \\
R1220 & 60 & 5 & 19 & 3 & 2 & 11 \\
R1240 & 61 & 4 & 21 & 2 & 0 & 13 \\
R1260 & 64 & 4 & 20 & 0 & 0 & 12 \\
R1280 & 65 & 3 & 19 & 0 & 0 & 13 \\
\hline
\end{tabular}

Figure 9 shows SEM images of the samples fired at $1180-1280^{\circ} \mathrm{C}$. As the sintering temperature increases, the raw-material particles gradually form a vitreous phase and the number of pores in the samples decreases (Figure 9a-e). The porosity reaches the lowest at $1260{ }^{\circ} \mathrm{C}$ (Figure 9e), while the diameter of the closed pores increases significantly at $1280^{\circ} \mathrm{C}$ (Figure $9 \mathrm{f}$ ), which can reduce the compactness and rupture modulus of the sample, indicating that the firing temperature of the sample should not exceed $1260^{\circ} \mathrm{C}$.
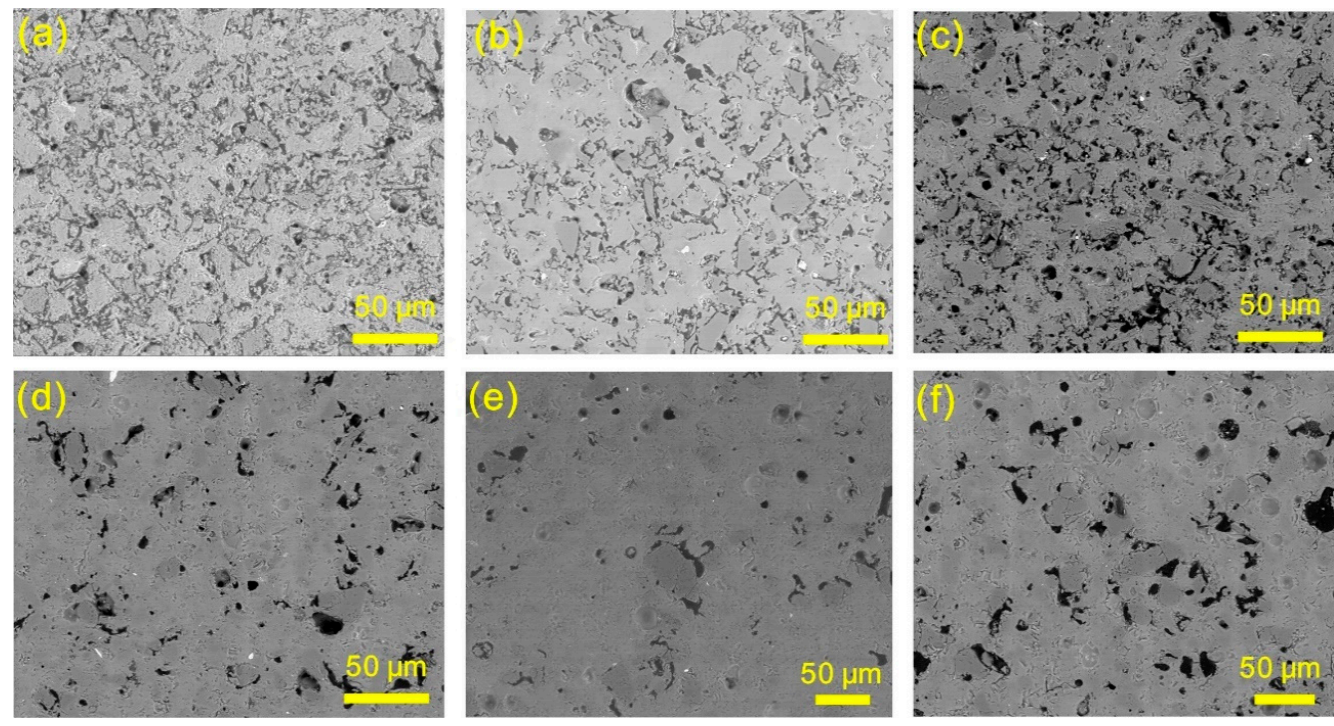

Figure 9. SEM micrographs of samples fired at (a) $1180{ }^{\circ} \mathrm{C}$; (b) $1200{ }^{\circ} \mathrm{C}$; (c) $1220{ }^{\circ} \mathrm{C}$; (d) $1240{ }^{\circ} \mathrm{C}$; (e) $1260^{\circ} \mathrm{C}$; and (f) $1280^{\circ} \mathrm{C}$. 
Table 4 shows the technological characteristics of the sintered ceramic tiles. When the firing temperature increased from $1180^{\circ} \mathrm{C}$ to $1260^{\circ} \mathrm{C}$, the water absorption of the samples decreased from $11.2 \%$ to $0.3 \%$, and the rupture modulus increased from $24 \mathrm{MPa}$ to $61 \mathrm{MPa}$. The fracture modulus of the samples decreased to $59 \mathrm{MPa}$ for a firing temperature of $1280^{\circ} \mathrm{C}$, which was due to the increase of the closed porosity. The water absorption and rupture modulus of the samples fired at $1260-1280^{\circ} \mathrm{C}$ are in line with the international standards ISO 13006 for porcelain tiles. The water absorption and rupture modulus results show that the lowest firing temperature to produce porcelain tiles meeting international standards is $1260^{\circ} \mathrm{C}$, which is higher than that of most porcelain tiles made from waste materials. In fact, the firing temperature of porcelain tiles prepared from natural mineral waste is usually higher than that of industrial waste because the flux in industrial waste is higher in content, or more diversified, such as in waste glass $[1,44]$ and fly ash $[24,28]$.

Table 4. Technological characteristics of ceramic tiles produced by SCW, calcined kaolin, and feldspar.

\begin{tabular}{|c|c|c|c|c|c|c|c|c|}
\hline Ref & $\begin{array}{c}\text { Water } \\
\text { Absorption } \\
(\%)\end{array}$ & $\begin{array}{l}\text { Rupture } \\
\text { Modulus } \\
\text { (MPa) }\end{array}$ & $\begin{array}{c}\text { Firing } \\
\text { Shrinkage } \\
\left(\mathrm{cm} \cdot \mathrm{m}^{-1}\right)\end{array}$ & $\begin{array}{c}\text { Bulk } \\
\text { Density } \\
\left(\mathrm{g} \cdot \mathrm{cm}^{-1}\right)\end{array}$ & $\begin{array}{c}\text { True } \\
\text { Density } \\
\left(\mathrm{g} \cdot \mathrm{cm}^{-1}\right)\end{array}$ & $\begin{array}{c}\text { Open } \\
\text { Porosity } \\
(\%)\end{array}$ & $\begin{array}{l}\text { Closed } \\
\text { Porosity } \\
(\%)\end{array}$ & $\begin{array}{c}\text { Total } \\
\text { Porosity } \\
(\%)\end{array}$ \\
\hline R1180 & $11.2 \pm 0.8$ & $24 \pm 3.0$ & $3.8 \pm 0.1$ & $1.90 \pm 0.01$ & $2.57 \pm 0.02$ & $21.3 \pm 0.6$ & $4.7 \pm 0.4$ & $26.0 \pm 1.1$ \\
\hline R1200 & $7.1 \pm 0.7$ & $37 \pm 1.4$ & $5.9 \pm 0.1$ & $2.08 \pm 0.02$ & $2.35 \pm 0.02$ & $14.8 \pm 0.8$ & $3.2 \pm 0.4$ & $18.0 \pm 1.3$ \\
\hline R1220 & $3.8 \pm 0.4$ & $45 \pm 2.5$ & $8.1 \pm 0.2$ & $2.25 \pm 0.02$ & $2.29 \pm 0.01$ & $8.5 \pm 0.5$ & $1.4 \pm 0.2$ & $10.0 \pm 0.6$ \\
\hline R1240 & $1.2 \pm 0.2$ & $59 \pm 1.7$ & $9.2 \pm 0.2$ & $2.31 \pm 0.01$ & $2.18 \pm 0.02$ & $2.7 \pm 0.1$ & $2.8 \pm 0.1$ & $5.5 \pm 0.2$ \\
\hline R1260 & $0.3 \pm 0.1$ & $61 \pm 1.5$ & $9.8 \pm 0.3$ & $2.29 \pm 0.01$ & $2.14 \pm 0.02$ & $0.5 \pm 0.1$ & $4.3 \pm 0.2$ & $4.8 \pm 0.2$ \\
\hline R1280 & $0.1 \pm 0.1$ & $59 \pm 2.6$ & $7.0 \pm 0.1$ & $2.23 \pm 0.02$ & $2.11 \pm 0.01$ & $0.2 \pm 0.1$ & $8.5 \pm 0.4$ & $8.8 \pm 0.3$ \\
\hline
\end{tabular}

The lowest firing temperature for preparing porcelain tiles from recycled waste was recently reported to be between $1100^{\circ} \mathrm{C}$ and $1300{ }^{\circ} \mathrm{C}$ [24-26,49]. The firing temperature of porcelain tiles can be reduced to $1070{ }^{\circ} \mathrm{C}$ by introducing $\mathrm{LO}$ in this experiment. The environmental and economic benefits of these new porcelain tiles can be estimated. Unlike high-grade spodumene, the price of low-grade LO used in this study is almost the same as that of traditional feldspar ( $80 \$ / t$, China), and the price of the SCW is also very low because it has not been effectively recycled. In terms of the sintering process, the firing temperature of modified triaxial ceramics can be reduced by $190^{\circ} \mathrm{C}$ by adding $\mathrm{LO}$, which reduces the consumption of natural gas and is conducive to the realization of low carbon emissions and sustainable production.

\section{Conclusions}

The work presented here aimed to study the effect of low-grade $\mathrm{LO}\left(2.7 \% \mathrm{Li}_{2} \mathrm{O}\right)$ on reducing the firing temperature of ceramic tile. The recycling of SCW and the application of calcined kaolin in ceramics were also tested. The phase composition and technological characteristics of porcelain tiles were precisely controlled by adjusting the composition and temperature of the new $\mathrm{SiO}_{2}-\mathrm{Al}_{2} \mathrm{O}_{3}-\mathrm{Na}_{2} \mathrm{O}-\mathrm{K}_{2} \mathrm{O}-\mathrm{Li}_{2} \mathrm{O}$ system.

When the firing temperature is $1040-1100{ }^{\circ} \mathrm{C}, 0-19 \%$ secondary mullite could be formed, and more quartz and cristobalite was retained, which proved to be beneficial to increase the rupture modulus of ceramics. As the firing temperature increased to $1100-1600^{\circ} \mathrm{C}$, the above crystal contents decreased rapidly, and the vitreous-phase contents increased, which lead to the expansion of closed pores in the sample. The compactness and rupture modulus of ceramics can be reduced at the same time. On the other hand, when the LO content is $10-20 \%$ and $50 \%$, there will be more feldspar and spodumene, respectively, in fired ceramic bodies. In contrast, feldspar and spodumene almost participate in the sintering reaction at LO content of $30-40 \%$. Finally, the ceramics with lower sintering temperature and higher compactness and rupture modulus were found concentrated in the range of 30-40\% LO and $1070-1100{ }^{\circ} \mathrm{C}$. Impermeable porcelain tile with a water absorption of $0.02 \%$ and a rupture modulus of $45 \mathrm{MPa}$ can be obtained at a lower firing temperature $\left(1070{ }^{\circ} \mathrm{C}\right)$ by adding $30 \% \mathrm{LO}$ and $20 \% \mathrm{SCW}$. While the content of $\mathrm{LO}$ in the sample is $0 \%$, the porcelain tile can be obtained only at $1260{ }^{\circ} \mathrm{C}$. Moreover, a 
porcelain tile with very high rupture modulus $(107 \mathrm{MPa})$ and low water absorption $(0.04 \%)$ can be obtained at $10 \% \mathrm{LO}$ and $1160{ }^{\circ} \mathrm{C}$.

The results show that the firing temperature of porcelain tiles can be reduced by adding low-grade LO instead of feldspar, without increasing the cost of raw materials, and SCW can be recycled as raw materials instead of quartz, which is conducive to reducing energy consumption in the industry and achieving sustainable development.

Supplementary Materials: The following are available online at http://www.mdpi.com/2075-163X/9/12/731/s1. Table S1: Phase data of porcelain tiles; Table S2: Technological parameter data of porcelain tiles; File XRD1: XRD data of S10-S50; File XRD2: XRD data of R1180-R1280.

Author Contributions: Data curation, L.P.; funding acquisition, S.Q.; methodology, L.P.; project administration, S.Q.; resources, S.Q.; software, L.P.; supervision, S.Q.

Funding: This research received no external funding.

Conflicts of Interest: The authors declare no conflicts of interest.

\section{References}

1. Raimondo, M.; Zanelli, C.; Matteucci, F.; Guarini, G.; Dondi, M.; Labrincha, J.A. Effect of waste glass (TV/PC cathodic tube and screen) on technological properties and sintering behaviour of porcelain stoneware tiles. Ceram. Int. 2007, 33, 615-623. [CrossRef]

2. Tucci, A.; Esposito, L.; Rastelli, E.; Palmonari, C.; Rambaldi, E. Use of soda-lime scrap-glass as a fluxing agent in a porcelain stoneware tile mix. J. Eur. Ceram. Soc. 2004, 24, 83-92. [CrossRef]

3. Matteucci, F.; Dondi, M.; Guarini, G. Effect of soda-lime glass on sintering and technological properties of porcelain stoneware tiles. Ceram. Int. 2002, 28, 873-880. [CrossRef]

4. Wang, W.; Chen, W.; Liu, H.; Han, C. Recycling of waste red mud for production of ceramic floor tile with high strength and lightweight. J. Alloys Compd. 2018, 748, 876-881. [CrossRef]

5. Huang, T. Latest Data of American Ceramic Brick Market. Available online: http://www.xbcd.cn/hyxw/jjgc/ 201905/499691822.html (accessed on 16 May 2019).

6. Matthew, G.O.; Fatile, B.O. Characterization of vitrified porcelain tiles using feldspar from three selected deposits in Nigeria. Res. J. Recent Sci. 2014, 3, 2277-2502.

7. Yue, L. Experimental study on preparation of vitrified brick from coal gangue (in Chinese). J. Liaoning Technol. Univ. (Nat. Sci.) 2010, 29, 201-204.

8. Dana, K.; Das, S.K. Enhanced resistance to thermal cycling of slag-containing vitrified porcelain tiles. Ceram. Int. 2008, 28, 121-124.

9. Pinatti, D.G.; Conte, R.A.; Borlini, M.C.; Santos, B.C.; Oliveira, I.; Vieira, C.M.F.; Monteiro, S.N. Incorporation of the ash from cellulignin into vitrified ceramic tiles. J. Eur. Ceram. Soc. 2006, 26, 305-310. [CrossRef]

10. Tulyaganov, D.U.; Agathopoulos, S.; Fernandes, H.R.; Ferreira, J.M.F. Influence of lithium oxide as auxiliary flux on the properties of triaxial porcelain bodies. J. Eur. Ceram. Soc. 2006, 26, 1131-1139. [CrossRef]

11. Ismatova, R. Properties and structure of spodumene-porcelain. Glass Ceram. 1987, 44, 314-316. [CrossRef]

12. Yamuna, A.; Devanarayanan, S.; Lalithambika, M. Mullite- $\beta$-spodumene composites from aluminosilicates. J. Am. Ceram. Soc. 2001, 84, 1703-1709. [CrossRef]

13. Low, I.M.; Mathews, E.; Garrod, T.; Zhou, D.; Phillips, D.N.; Pillai, X.M. Processing of spodumene-modified mullite ceramics. J. Mater. Sci. 1997, 32, 3807-3812. [CrossRef]

14. Oberžan, M.; Holc, J.; Buh, M.; Kuščer, D.; Lavrač, I.; Kosec, M. High-alumina porcelain with the addition of a $\mathrm{Li}_{2} \mathrm{O}$-bearing fluxing agent. J. Eur. Ceram. Soc. 2009, 29, 2143-2152. [CrossRef]

15. Bayuseno, A.P.; Latella, B.A.; O'Connor, B.H. Resistance of alumina spodumene ceramics to thermal shock. J. Am. Ceram. Soc. 1999, 82, 819-824. [CrossRef]

16. Zhou, J.E.; Liu, K.; Dong, W.X.; Bao, Q.F.; Zhao, T.G.; Wang, Y.Q. Effects of CaO- $\mathrm{Li}_{2} \mathrm{O}-\mathrm{K}_{2} \mathrm{O}-\mathrm{Na}_{2} \mathrm{O}$ fluxing agents on the properties of porcelain ceramic tiles. Key Eng. Mater. 2015, 655, 258-262. [CrossRef]

17. Sheng, Y. Business Club: Spodumene Price of Zhongjin Taifu Mining Co. Ltd. Stayed Stable on July 12. Available online: http://www.100ppi.com/news/detail-20190712-1481629.html (accessed on 12 July 2019).

18. Sánchez, E.; García-Ten, J.; Sanz, V.; Moreno, A. Porcelain tile: Almost 30 years of steady scientific-technological evolution. Ceram. Int. 2010, 36, 831-845. [CrossRef] 
19. Lemougna, P.N.; Yliniemi, J.; Ismailov, A.; Levanenb, E.; Tanskanenc, P.; Kinnunena, P.; Roningd, J.; Illikainena, M. Spodumene tailings for porcelain and structural materials: Effect of temperature $\left(1050-1200{ }^{\circ} \mathrm{C}\right)$ on the sintering and properties. Miner. Eng. 2019, 141, 105843. [CrossRef]

20. Dhanapandian, S.; Manoharan, C.; Ramkumar, T.; Gnanavela, B.; Sutharsana, P.; Shanthi, M. Effect of incorporation of granite and marble rejects in clay brick products: Physico-mechanical analysis. Acta Phys. Pol. A 2010, 118, 688-694. [CrossRef]

21. Saboya, F., Jr.; Xavier, G.C.; Alexandre, J. The use of the powder marble by-product to enhance the properties of brick ceramic. Constr. Build. Mater. 2007, 21, 1950-1960. [CrossRef]

22. Souza, A.J.; Pinheiro, B.C.A.; Holanda, J.N.F. Recycling of gneiss rock waste in the manufacture of vitrified floor tiles. J. Environ. Manag. 2010, 91, 685-689. [CrossRef]

23. Pinheiro, B.C.A.; Holanda, J.N.F. Obtainment of porcelain floor tiles added with petroleum oily sludge. Ceram. Int. 2013, 39, 57-63. [CrossRef]

24. Luo, Y.; Zheng, S.; Ma, S.; Liu, C.; Wang, X. Ceramic tiles derived from coal fly ash: Preparation and mechanical characterization. Ceram. Int. 2017, 43, 11953-11966. [CrossRef]

25. Ji, R.; Zhang, Z.T.; Yan, C.; Zhu, M.G.; Li, Z.M. Preparation of novel ceramic tiles with high $\mathrm{Al}_{2} \mathrm{O}_{3}$ content derived from coal fly ash. Constr. Build. Mater. 2016, 114, 888-895. [CrossRef]

26. Ke, S.J.; Wang, Y.M.; Pan, Z.D.; Ning, C.Y.; Zheng, S.L. Recycling of polished tile waste as a main raw material in porcelain tiles. J. Clean. Prod. 2016, 115, 238-244. [CrossRef]

27. Dana, K.; Dey, J.; Das, S.K. Synergistic effect of fly ash and blast furnace slag on the mechanical strength of traditional porcelain tiles. Ceram. Int. 2005, 31, 147-152. [CrossRef]

28. Das, S.K.; Pal, M.; Ghosh, J.; Pathi, K.V.; Mondal, S. The effect of basic oxygen furnace slag and fly ash additions in triaxial porcelain composition: Phase and micro structural evolution. Trans. Indian Inst. Met. 2013, 66, 213-220. [CrossRef]

29. Patrick, D.O.; Kefas, H.M.; John, Y.M.; Ameh, V.I. Investigation of the physical properties of tiles produced with Otukpo clay. Leonardo Electron. J. Pract. Technol. 2015, 27, 162-176.

30. Manoharan, C.; Sutharsan, P.; Dhanapandian, S.; Venkatachalapathy, R.; MohamedAsanulla, R. Analysis of temperature effect on ceramic brick production from alluvial deposits, Tamilnadu, India. Appl. Clay Sci. 2011, 54, 20-25. [CrossRef]

31. Liu, J.; Peng, L.; Qin, S. Structure and properties of the fused quartz crucibles for silicon ingots in sintering and casting process. J. Synth. Cryst. 2016, 45, 1261-1265. (In Chinese with English abstract)

32. Zhou, J.; Ma, G.Y.; Ma, R. Quantitative analysis on amorphous phase content in blast furnace slag. Phys. Test Chem. Anal. Part A 2015, 51, 711-716.

33. Peng, L.; Qin, S. Mechanical behaviour and microstructure of an artificial stone slab prepared using a waste $\mathrm{SiO}_{2}$ crucible and quartz. Constr. Build. Mater. 2018, 50, 273-280. [CrossRef]

34. GB/T 1548-2015, Test Method for Linear Shrinkage of Ceramic Body Slurry; Ministry of Industry and Information Technology of People's Republic of China: Beijing, China, 2015. (In Chinese)

35. GB/T 3810.3-2006, Test Methods of Ceramic Tiles: Determination of Water Absorption, Apparent Porosity, Apparent Relative Porosity and Bulk Density; Standardization Administration of the People's Republic of China: Beijing, China, 2006. (In Chinese)

36. GB/T 3810.4-2006, Test Methods of Ceramic Tiles-Part 4: Determination of Modulus of Rupture and Breaking Strength; Standardization Administration of the People's Republic of China: Beijing, China, 2006. (In Chinese)

37. QB/T 1010-2015, Test Methods of for True Density of Ceramic Materials and Pigment; Ministry of Industry and Information Technology of People's Republic of China: Beijing, China, 2015. (In Chinese)

38. Stevens, S.J.; Hand, R.J.; Sharp, J.H. Polymorphism of silica. J. Mater. Sci. 1997, 32, 2929-2935. [CrossRef]

39. Marians, C.S.; Hobbs, L.W. Network properties of crystalline polymorphs of silica. J. Non-Cryst. Solids 1990, 124, 242-253. [CrossRef]

40. Castelein, O.; Guinebretiere, R.; Bonnet, J.P.; Blanchart, P. Shape, size and composition of mullite nanocrystals from rapidly sintered kaolin. J. Eur. Ceram. Soc. 2001, 21, 2369-2376. [CrossRef]

41. Iqbal, Y.; Lee, W.E. Fired porcelain microstructures revisited. J. Am. Ceram. Soc. 1999, 82, 3384-3390. [CrossRef]

42. Iqbal, Y.; Lee, W.E. Microstructural evolution in triaxial porcelain. J. Am. Ceram. Soc. 2000, 83, 3121-3127. [CrossRef] 
43. Lu, H.Y.; Wang, W.L.; Tuan, W.H.; Lin, M.H. Acicular mullite crystals in vitrified kaolin. J. Am. Ceram. Soc. 2004, 87, 1843-1847. [CrossRef]

44. Gualtieri, M.L.; Mugoni, C.; Guandalini, S.; Cattini, A.; Mazzini, D.; Alboni, C.; Siligardi, C. Glass recycling in the production of low-temperature stoneware tiles. J. Clean. Prod. 2018, 197, 1531-1539. [CrossRef]

45. Luz, A.P.; Ribeiro, S. Use of glass waste as a raw material in porcelain stoneware tile mixtures. Ceram. Int. 2007, 33, 761-765. [CrossRef]

46. Tucci, A.; Esposito, L.; Malmusi, L.; Rambaldi, E. New body mixes for porcelain stoneware tiles with improved mechanical characteristics. J. Eur. Ceram. Soc. 2007, 27, 1875-1881. [CrossRef]

47. Falamaki, C.; Afarani, M.S.; Aghaie, A. Initial sintering stage pore growth mechanism applied to the manufacture of ceramic membrane supports. J. Eur. Ceram. 2004, 24, 2285-2292. [CrossRef]

48. ISO 13006, Ceramic Tiles-Definitions, Classification, Characteristics and Marking; Technical Committee: ISO/TC 189 Ceramic Tile; ISO: Geneva, Switzerland, 2012.

49. Gouvêa, D.; Kaneko, T.T.; Kahn, H.; Conceição, E.S.; Antoniassi, J.L. Using bone ash as an additive in porcelain sintering. Ceram. Int. 2015, 41,487-496. [CrossRef]

(C) 2019 by the authors. Licensee MDPI, Basel, Switzerland. This article is an open access article distributed under the terms and conditions of the Creative Commons Attribution (CC BY) license (http://creativecommons.org/licenses/by/4.0/). 